\title{
ОГЛЯД МЕТОДІВ ПОБУДОВИ СИСТЕМ КЕРУВАННЯ МЕХАНІЗМОМ ПАРАЛЕЛЬНОЇ КІНЕМАТИЧНОЇ СТРУКТУРИ НА ОСНОВІ ПЛАТФОРМИ СТЮАРТА (ГЕКСАПОД)
}

\author{
Зозуля В.А. ${ }^{1}$, Осадчий С.I. ${ }^{2}$ \\ ${ }^{1,2}$ Центральноукраїнський національний технічний університет, м. Кропівницький, Україна \\ ${ }^{1}$ к.т.н., доцент, ${ }^{2}$ д.т.н., проф. \\ ORCID: ${ }^{1}$ https://orcid.org/0000-0003-3793-4686, ${ }^{2}$ https://orcid.org/0000-0002-1811-3594 \\ E-mail: ${ }^{1}$ irish38@ukr.net, ${ }^{2}$ srg2005@ukr.net
}

Copyright ( 2018 by author and the journal “Automation technologies and business - processes. This work is licensed under the Creative Commons Attribution International License (CC BY). http://creativecommons.org/licanses/by/4.0

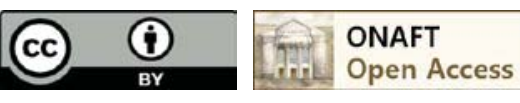

DOI:

\begin{abstract}
Аннотация: Метою даної статті є вивченні сформованих методів, прийомів $і$ принципів розробки систем керування рухом робочого органу платформи Стюарта (гексапод) для визначення шляхів вдосконалення їх характеристик. Як показано в аналізі, проектування систем керування рухом робочого органу гексаподу поділяються на два основних напрямка: метод керування рухом в робочому просторі при вирішенні прямої задачі кінематики та керуванням рухом в просторі узагальненої координати при вирішенні зворотної задачі кінематики. Аналіз методів розробки систем керування рухом робочого органу платформи Стюарта, який показав, щзо з метою спрощення моделі об'єкта керування і процедур проектування системи керування, часто пропонується поділ механізму на окремі автономні канали за кількістю итанг платформи Стюарта, нехтуючи похибками вимірювання $i$ динамікою датчиків, використання ідеалізованих віртуальних моделей механізму паралельної кінематики для формування сигналів корекиії. При изьому замінюються реальні характеристики платформи Стюарта лінеаризованими, а збурюючі дї̈ - взаємовпливом висей їх оцінками. Для деяких режимів роботи гексаподу спрощена модель динаміки не буде відображати реальних фізичних прочесів, щзо відбуваються в гексаподі, щуо негативно позначається на керованості механізму в цілому. Проведений аналіз дозволив запропонувати структурні схеми керування рухом робочого органу гексаподу побудовані за принципом одно, двоконтурних слідкуючих систем. Виходячи з недоліків слідкуючих систем, запропоновано будувати систему керування гексаподом на основі схем що мають потенційно більшу точність відтворення програмного керування за рахунок збільшення ступеня вільності у виборі регулятора.

Abstract: The purpose of this article is to study the existing methods, techniques and principles for developing systems for controlling the movement of the working body of the Stewart platform (hexapod) to determine ways to improve their characteristics. As shown in the analysis, the design of control systems for the movement of the hexapod working body is divided into two main directions: the method of controlling motion in the Task Space in solving the direct task of kinematics and controlling motion in the Joint Space in solving the inverse task of kinematics. Analysis methods for developing systems working body motion control platform Stewart, who showed that in order to simplify control object models and procedures for designing control systems, it is often proposed to divide the mechanism into separate autonomous channels by the number of Stewart platform rods, neglecting the measurement errors and the dynamics of sensors, the use of idealized virtual models of the mechanism of parallel kinematics for the formation of correction signals. In this case, the real characteristics of the Stewart platform are replaced by linearized, and perturbing action are mutually influential by their estimates. For some modes of hexapod simplified model of dynamics will not reflect the real physical processes occurring in the hexapod, which adversely affects the controllability of the mechanism as a whole. The analysis made it possible to propose the motion control block diagrams of the working body of the hexapod built on the principle of one, two-track follow-up systems. Based on the shortcomings of follow-up systems, it is proposed to build a hexapod control system based on schemes that have a potentially greater accuracy of program control playback by increasing the degree of freedom in the choice of the controller.
\end{abstract}

Ключові слова: системи, управління, об'єкт, гексапод, структурні схеми

Keywords: system, control, object, hexapod, structural schemes 


\section{Вступ.}

Під просторовим механізмом паралельної кінематичної структури (МПС) або паралельним механізмом розуміють багатоступеневий механізм, що складається з декількох, однотипних кінематичних ланцюгів, замкнутих на загальну нерухому основу з одного боку і - на рухому платформу 3 іншого. Кінематичні ланцюги складаються 3 жорстких ланок і рухомих вузлів, що з'єднують їх. У зв'язку з тим, що число, вид і порядок кінематичних пар в ланцюгах може бути різним, різноманіття механізмів паралельної структури дуже велике, за оцінками [1] на даному етапі розвитку техніки існує понад 100 видів МПС.

Особливий інтерес представляє механізми паралельної кінематичної структури на основі платформи Стюарта (гексапод), яка має шість однотипних кінематичних ланцюгів (штанг) [2]. Програмно регулюючи довжину штанг, можна управляти положенням вихідної ланки, переміщати його в вертикальному і горизонтальному напрямках, повертати в трьох площинах.

Платформа Стюарта (гексапод) складається з нерухомої основи 1, рухомої платформи 2 і шести штанг, довжина $l$, яких змінюється за допомогою приводів (рис. 1). Будемо розглядати дві системи координат: інерційну $O_{0} X_{0} Y_{0} Z_{0}$, пов'язаним з центром нерухомої основи $O_{0}$, і рухому $O_{1} X_{1} Y_{1} Z_{1}$, пов'язану з центом мас платформи (робочим органом) $\mathrm{O}_{1}$.

Координати робочого органу в загальному випадку являє собою вектор $r=(x, y, z, \alpha, \beta, \gamma)^{\prime}$, де / - символ транспонування вектора. Він характеризуються лінійними переміщеннями $(x, y, z$ координати центру обертання платформи $O_{1}$ ) характерної точки $O_{1}$ уздовж осей нерухомої системи координат $O_{0} X_{0} Y_{0} Z_{0}$, пов'язаної 3 центром нерухомого основи $O_{0}$. I кутовими переміщеннями: $\alpha$ - кут рискання, $\beta$ - кут тангажу (диферент), $\gamma$ - кут крену, які характеризують поворот рухомої платформи щодо власних осей рухомої системи координат $O_{1} X_{1} Y_{1} Z_{1}$, пов'язаної з центром рухомою платформою $O_{1}$. Довжина штанг зазвичай задаються у вигляді вектора $q=\left(l_{1}, l_{2}, \ldots, l_{6}\right)^{\prime}$, які прив'язані до нерухомої системі координат $O_{0} X_{0} Y_{0} Z_{0} 3$ центром $O_{0}$.

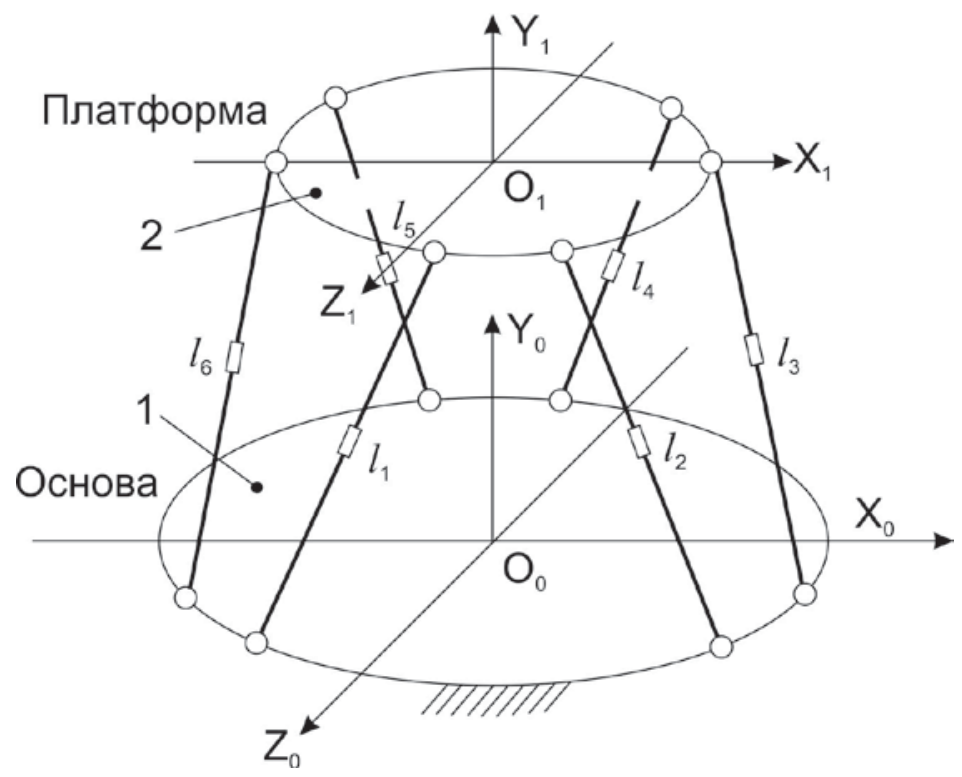

Рис. 1 Кінематична схема платформи Стюарта (гексапод)

Внаслідок специфічної побудови обладнання 3 механізмом паралельної структури йому властива нелінійна залежність між значеннями довжин штанг і положенням робочого органу [2]. У зв'язку з цим виникають завдання визначення координат робочого органу з відомим значенням довжин штанг (пряма задача кінематики) і визначення довжин штанг по відомих координатах робочого органу (зворотна задача кінематики). Тоді пряма задача кінематики записується у вигляді

$$
\Delta \mathrm{X}=J \Delta q
$$

де $\Delta q$ - вектор прирощення довжин штанг; $\Delta \mathrm{X}$ - вектор прирощення координат $x, y, z, \alpha, \beta, \gamma ; J-$ якобіан (матриця Якобі) [2], який може бути записаний у вигляді

а зворотна задача кінематики відповідно

$$
J=\left\lfloor J_{1}, J_{2}, \ldots, J_{6}\right\rfloor
$$

$$
\Delta q=J^{-1} \Delta \mathrm{X}
$$


Аналіз літературних даних і постановка проблеми.

Активне впровадження МПС на основі платформи Стюарта (гексапод) у виробництво до недавнього часу стримував низький рівень обчислювальної техніки, що не дозволяв вирішувати завдання керування МПС. Механізми паралельної структури здатні забезпечити досить високі динамічні характеристики при відносно невеликій металоємності.

Дослідження МПС даного класу мають велике значення і дуже актуально, важливою частиною даних досліджень є розробка системи керування рухом механізму, виходячи із заданих вимог, що пред'являються до системи. Однак, досягнення бокові динамічних характеристик такими механізмами можливо тільки в результаті розробки і впровадження оптимальних систем керування [16]. Структура і параметри зазначених систем повинні бути знайдені в результаті синтезу по [15] і реалізовані засобами сучасної швидкодіючої мікропроцесорної техніки.

\section{Мета і завдання дослідження.}

Завдання даної статті полягає у вивченні сформованих методів, прийомів і принципів розробки систем керування МПС типу гексапод для визначення шляхів вдосконалення їх характеристик.

\section{1. Класифікація існуючих систем керування рухом гексаподу}

Рівняння динаміки паралельного маніпулятора має нелінійний характер, що залежить від конфігурації [2]. Тому знайти потрібний регулятор, щоб домогтися необхідної продуктивності у всіх конфігураціях, є важким завданням. Методи керування рухом МПС типу гексапод (6 DOF) при вирішенні прямої задачі кінематики, коли передбачається, що заданий вектор руху робочого органу X і потрібно визначити вектор довжин штанг гексапод q, прийнято називати як методи керування рухом в робочому просторі. Методи керування при вирішенні зворотної задачі кінематики, коли вектор руху робочого органу $\mathrm{X}$ визначають на підставі значення вектора довжин штанг гексапод q, називають керуванням рухом в просторі узагальненої координати [3,4].

Керування рухом робочого органу гексапод в робочому просторі може бути реалізовано тільки після того, як стану системи 6 DOF визначаються шляхом дорогих прямих вимірювань або досить громіздкої оцінки стану. При цьому можна забезпечити якісне керування 6 ступенями вільності при невизначеності системи: інерції, помилки моделювання, тертя і т. д. Також цей підхід має деякі алгоритмічні складності і чисельні труднощі через використання прямої задачі кінематики, які описуються складними нелінійними рівняннями. Виконати керування рухом робочого органу гексапод в робочому просторі, стає набагато складніше, якщо рішення прямої задачі кінематики необхідно обчислювати в режимі реального часу.

Керування рухом робочого органу гексапод в просторі узагальненої координати може бути легко реалізовано у вигляді набору з декількох незалежних, одновимірних систем керування (SISO) з використанням інформації тільки для окремого виконавчого механізму [17]. Така побудова системи керування призводить до того, що на виконавчому рівні складні динамічні об'єкти управління вважаються не розподіленими і взаємопов'язаними з виконавчими висями, а зосередженими та однозв'язні зі змінними динамічними параметрами і збуреннями, приведеними до валів виконавчих двигунів. Можливість синтезу законів керування в просторі узагальненої координати по окремим ступенях рухливості обумовлена також тим, що розрахунок параметрів алгоритмів виконується 3 урахуванням інерційно-масових характеристик кожної вісі окремо, при цьому перехресні зв'язки безпосередньо можуть враховуються в спеціалізованому обчислювачі як в роботі [7]. Як децентралізованих регуляторів виконавчих механізмів можуть бути використані різні типи регуляторів.

Автори [3-5] запропонували структурні схеми керування рухом гексапода в робочому просторі і просторі узагальненої координати. Ці схеми побудовані на основі одноконтурной, замкнутої системі, що стежить. У схемі керування в робочому просторі в колі зворотного зв'язку вирішується пряма задача кінематики, а в схемі керування в просторі узагальненої координати в прямому ланцюзі перед елементом порівняння вирішується зворотна задача кінематики. Регулятор в цих схемах розташований за елементом порівняння перед об'єктом керування (гексапод) і формує керуючий сигнал - сили / крутних моментів виконавчого механізму $\tau$, на підставі вектора помилки, який складається 3 шести компонентів $e_{q}=\left\lfloor e_{l_{1}} e_{l_{2}} e_{l_{3}} e_{l_{4}} e_{l_{5}} e_{l_{6}}\right\rfloor, e_{x}=\left\lfloor e_{x} e_{y} e_{z} e_{\alpha} e_{\beta} e_{\gamma}\right\rfloor$ відповідно в робочому просторі і просторі узагальненої координати. Ці структурні схеми мають ряд недоліків.

По-перше, не враховує похибки введення вектора програмного, керованого сигналу, нехтують динамікою інтелектуальних датчиків інформації і шумами, які супроводжують вимірювання, що обмежує можливості підвищення точності керування.

По-друге, згідно з [14] таке розташування регулятора обмежує його ступінь вибору, тим самим зменшує точність управління.

3 урахуванням цього можна запропонувати структурні схеми керування рухом робочого органу гексапод в робочому просторі і в просторі узагальненої координати рисунок 2 i 3. На рисунках 2 i 3 головний регулятор розподілений на три складові $\mathrm{W}_{1 \mathrm{q}}, \mathrm{W}_{2 \mathrm{q}}$ и $\mathrm{W}_{3 \mathrm{q}}$. Такий розподіл регулятора сприяє поліпшенню якості керування $\mathrm{i}$ дозволяє врахувати перехресні зв'язки всередині гексапод. 


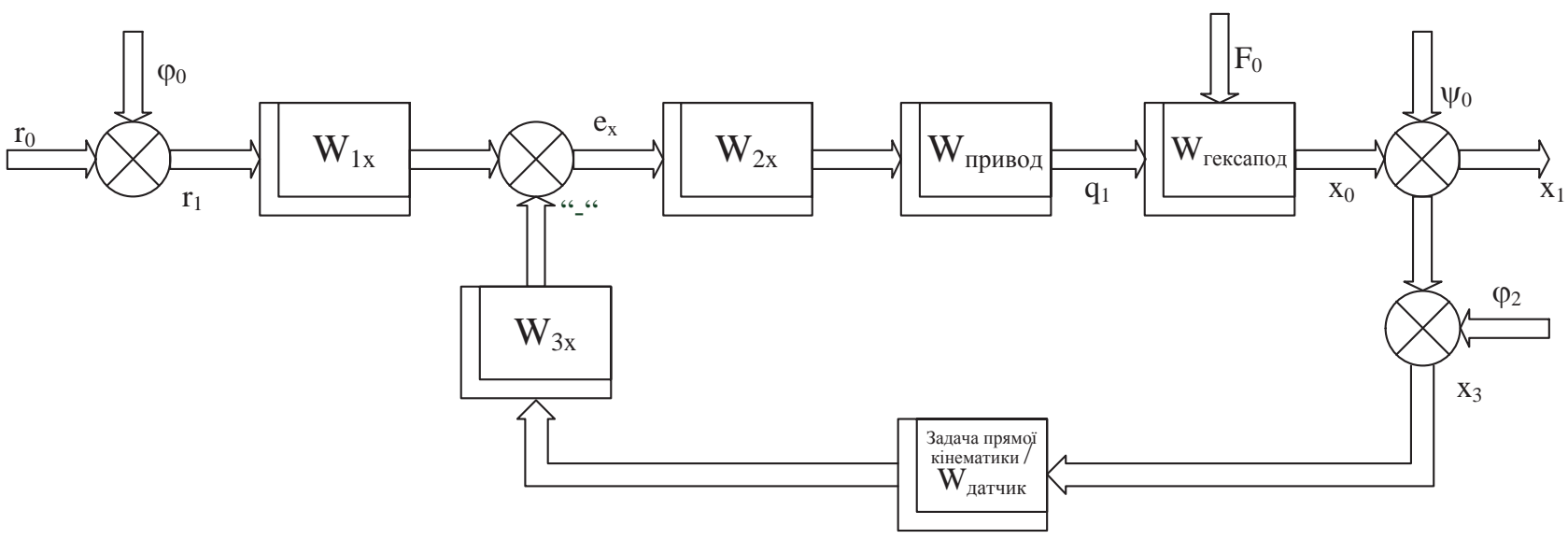

Рис. 2 Структурна схема керування на основі робочого простору

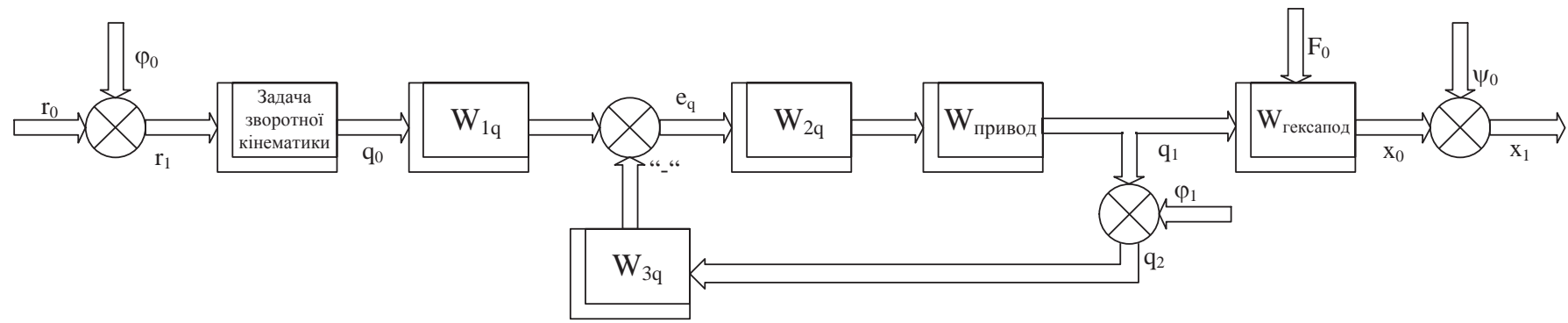

Рис. 3 Структурна схема керування в просторі узагальненої координати

У цих структурних схемах представлені наступні позначення:

$r_{0}$ - бажаний вектор програмного сигналу, задана траєкторія руху платформи (6DOF),

$$
r_{0}=\left[\begin{array}{llllll}
x_{0} & y_{0} & z_{0} & \alpha_{0} & \beta_{0} & \gamma_{0}
\end{array}\right]^{\prime},
$$

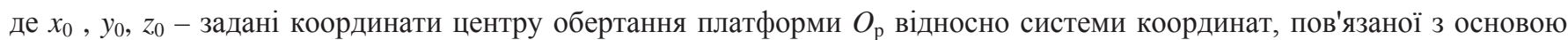
механізму $\mathrm{O}_{0} \mathrm{X}_{0} \mathrm{Y}_{0} \mathrm{Z}_{0}$ (рис.1); $\alpha_{0}$ - заданий кут рискання; $\beta_{0}$ - заданий кут тангажу (дифферента); $\gamma_{0}$ - заданий кут крену; / - символ транспонування вектора.

$\varphi_{0}$ - вектор похибок завдання програмних сигналів, який виникає внаслідок помилок інтерполяції та інших, які супроводжують формування вектора $\mathrm{r}_{1}$ на основі вектора $\mathrm{r}_{0}$ (формування траєкторії руху):

$$
\varphi_{0}=\left[\begin{array}{llllll}
\varphi_{x}^{0} & \varphi_{y}^{0} & \varphi_{z}^{0} & \varphi_{\alpha}^{0} & \varphi_{\beta}^{0} & \varphi_{\gamma}^{0}
\end{array}\right] .
$$

$\mathrm{r}_{1}$ - сформований (фактичний) вектор програмний сигналів (значення залежить від схеми і завдання):

$$
r_{1}=r_{0}+\varphi_{03}=\left[\begin{array}{llllll}
x_{1} & y_{1} & z_{1} & \alpha_{1} & \beta_{1} & \gamma_{1}
\end{array}\right]^{\prime} .
$$

$\mathrm{q}_{0}$ - визначений на основі вектора $\mathrm{r}_{1}$ в результаті вирішення зворотної задачі кінематики вектор заданих довжин штанг гексаподу:

$$
q_{0}=\left[\begin{array}{llllll}
l_{1}^{0} & l_{2}^{0} & l_{3}^{0} & l_{4}^{0} & l_{5}^{0} & l_{6}^{0}
\end{array}\right] .
$$

$\mathrm{q}_{2}$ - вектор виміряних значень довжин штанг гексаподу:

$$
q_{2}=q_{1}+\varphi_{1}=\left[\begin{array}{llllll}
l_{1}^{2} & l_{2}^{2} & l_{3}^{2} & l_{4}^{2} & l_{5}^{2} & l_{6}^{2}
\end{array}\right],
$$

де $\mathrm{q}_{1}$ - вектор справжніх довжин штанг гексаподу; $\varphi_{1}$ - вектор похибок вимірювання довжини штанг.

$X_{0}$ - вектор незбурених координат платформи відносно системи координат $\mathrm{O}_{0} \mathrm{X}_{0} \mathrm{Y}_{0} \mathrm{Z}_{0}$, який виникає при відсутності опору руху платформи:

$$
X_{0}=\left[\begin{array}{llllll}
x_{0}^{0} & y_{0}^{0} & z_{0}^{0} & \alpha_{0}^{0} & \beta_{0}^{0} & \gamma_{0}^{0}
\end{array}\right] .
$$

$\psi_{0}$ - вектор збурень, які змінюють координати платформи:

$$
\psi_{0}=\left[\begin{array}{llllll}
\psi_{x}^{0} & \psi_{y}^{0} & \psi_{z}^{0} & \psi_{\alpha}^{0} & \psi_{\beta}^{0} & \psi_{\gamma}^{0}
\end{array}\right] .
$$


$X_{1}$ - вектор справжніх значень координат платформи відносно системи координат $\mathrm{O}_{0} \mathrm{X}_{0} \mathrm{Y}_{0} \mathrm{Z}_{0}$ :

$$
X_{1}=X_{0}+\psi_{0}=\left[\begin{array}{llllll}
x_{1} & y_{1} & z_{1} & \alpha_{1} & \beta_{1} & \gamma_{1}
\end{array}\right] .
$$

$\varphi_{2}$ - вектор похибок вимірювання справжніх значень координат платформи:

$$
\varphi_{2}=\left[\begin{array}{llllll}
\varphi_{x}^{2} & \varphi_{y}^{2} & \varphi_{z}^{2} & \varphi_{\alpha}^{2} & \varphi_{\beta}^{2} & \varphi_{\gamma}^{2}
\end{array}\right] .
$$

$X_{3}$ - вектор виміряних значень координат платформи:

$$
X_{3}=f\left(X_{1}+\varphi_{2}\right)=\left[\begin{array}{llllll}
x_{3} & y_{3} & z_{3} & \alpha_{3} & \beta_{3} & \gamma_{3}
\end{array}\right] .
$$

$F_{0}$ - вектор проекцій рівнодіючих зусиль і моментів, які супроводжують рух платформи, на вісі системи координат, пов'язаної з платформою:

$$
F_{0}=\left[\begin{array}{llllll}
f_{o x} & f_{0 y} & f_{0 z} & m_{0 x} & m_{0 y} & m_{0 z}
\end{array}\right],
$$

$f_{0 x}, f_{0 y}, f_{0 z}-$ проекції рівнодіючих сил, які прикладені в точці $O_{1}$ до платформи, на вісі системи $\mathrm{O}_{1} \mathrm{X}_{1} \mathrm{Y}_{1} \mathrm{Z}_{1}$;

$m_{0 x}, m_{0 y}, m_{0 z}$ - проекції результуючого моменту сил, що діють на платформу, на вісі системи $\mathrm{O}_{1} \mathrm{X}_{1} \mathrm{Y}_{1} \mathrm{Z}_{1}$.

В роботі [5] запропоновано для компенсації шуму вимірювання і зовнішніх збурень, використовувати керування 3 прогнозуванням (регулювання по обуренню, Feed Forward Control). У структуру регулятора додається попереджувальні збурювання $F$, яке позначає узагальнену силу, в робочому просторі

$$
F_{f f}=\hat{M}\left(r_{1}\right) \cdot \ddot{r}_{1}+\hat{C}\left(r_{1}, \dot{r}_{1}\right) \cdot \dot{r}_{1}+\hat{G}\left(r_{1}\right),
$$

в просторі узагальненої координати

$$
\tau_{\text {ff }}=F_{\text {ff }} \cdot J^{-T},
$$

де $\hat{M}\left(r_{1}\right)$ - оцінка матриці маси гексаподу, $\hat{C}\left(r_{1}, \dot{r}_{1}\right)$ - оцінка матриці Коріоліса і відцентрової матриці, а також $\hat{G}\left(r_{1}\right)$ оцінка вектора сили ваги; $r_{1}$ - сформований вектор програмних сигналів узагальнених координат для положення $\mathrm{i}$ орієнтації платформи, що рухається, а відтак

$$
r=\left[\begin{array}{l}
x \\
\theta
\end{array}\right], \dot{r}=\left[\begin{array}{l}
v \\
\omega
\end{array}\right], \ddot{r}=\left[\begin{array}{l}
a \\
\dot{\omega}
\end{array}\right] .
$$

Цей метод має ряд недоліків. Найбільш важливим обмеженням цього методу керування є сувора, необхідна умова про повну визначеність матриць рівняння динаміки. Вивід, яких є дуже складним завданням, з урахуванням відсутності повної інформацією властивості гексаподу. 3 огляду на це, різниця між справжніми значеннями матриць рівняння динаміки гексаподу і їх оцінками можна розглядати як додаткове збурення, яке буде істотно впливати на статичну помилку стеження, що встановилася, замкнутої системи регулювання.

3 літературних джерел [5-7] відомо про використання для керування МПС методу зворотної задачі динаміки (IDC Inverse dynamics controller), або інша його назва метод обчислення моментів, що крутять. У цьому методі нелінійна динаміка моделі використовується в якості коригуючого члена до децентралізованого регулятору. Таким чином, нелінійна властивість паралельного маніпулятора 6 DOF значно послаблюються, i, отже, характеристики керування лінійним регулятором значно поліпшується. Коригувальні збурювання для схеми в робочому просторі,

$$
F_{f l}=\hat{C}\left(r_{1}, \dot{r}_{1}\right) \cdot \dot{r}_{1}+\hat{G}\left(r_{1}\right),
$$

а для схеми в просторі узагальненої координати

$$
\tau_{f l}=F_{f l} \cdot J^{-T}
$$

додаються в структуру зворотного зв'язку, локально охоплюючи модель гексапод. Крім того, оцінка матриці маси гексаподу додається в прямому контурі на додаток до бажаного прискоренню траєкторії $\ddot{r}_{q}$ та $\ddot{r}_{x}$ після регулятора для схеми в робочому просторі і в просторі узагальненої координати відповідно.

Цей метод керування дуже популярний на практиці через те, що може значно линеаризовать і відокремити модель динаміки від помилки динаміки в замкнутому контурі. Крім того, помилки динаміки не залежать від конфігурації, і, отже, набагато легше налаштувати коефіцієнт підсилення регулятора для відповідної характеристики у всьому робочому просторі гексаподу.

Можна помітити в якості недоліків даного методу, що розрахунок коригуючого члена здійснюють на основі бажаних значень положень і швидкостей механізму, що є менш точним по постановці завдання, а також ту обставину, що для формування необхідного закону керування необхідно в режимі реального часу вирішувати велику кількість диференціальних рівнянь.

Важливим підходом до модифікації керування за допомогою зворотної задачі динаміки, полягає в розгляді повної лінеаризації, при припущенні, що повне визначення матриць рівняння динаміки неможливо. Щоб компенсувати цей недолік, в літературі [5,8-11] запропоновані вдосконалені методи керування, а саме робастний, адаптивний та Нळ контроль. 
У статтях [8,9] наведено дослідження для розробки робастного нелінійного контролера, в робочому просторі для паралельного маніпулятора 36 DOF. Пряма задача кінематики вирішується методом Ньютона-Рафсона, в той час як альфа-бета-трекер застосовується для подальшої обробки отриманих 6 DOF-даних, тим самим здійснює фільтрацію лінійних / кутових положень та їх похідних (замість дорогого датчика $3 \mathrm{~d}$ стану). На додаток до непрямих оцінок стану 6 DOF, вводиться оцінка тертя Фрідланда-Парку в просторі узагальненої координати, яка допомагає компенсувати фрикційні збурення в виконавчих механізмах.

У статті [10] пропонується робастна схема для керування паралельним роботизованим маніпулятором 3 використанням принципу керування активною силою (Active Force Control (AFC)), яка вбудовується в контур керування з ПІД регулятором. Головна мета схеми з АFC полягає в тому, щоб забезпечити ефективну компенсацію нелінійної динаміки, що виникає через перешкоди і невизначеностей, без зниження продуктивності всієї системи. $\mathrm{AFC}$, використовує простий алгоритм, заснований на оцінці або виміряних значеннях відповідних параметрів. Тому для здійснення можливості придушення перешкод це не вимагає великих обчислювальних і математичних операцій.

У статті [11], в якості контролера керування для платформи Стюарта пропонується контролер 3 лінеаризованою зворотною динамікою в поєднанні з робастних контролером Нळ. Платформа Стюарта, має недолік - відносно невелика робоча область у порівнянні з послідовним маніпулятором. Однак ця характеристика дозволяє залежним від конфігурації матрицями нелінійних коефіцієнтів рівняння динаміки наближатися до постійних, не вносячи великих помилок моделювання. На основі цих постійних матриць розрахунок лінеаризованної зворотної динаміки стає набагато простіше (зменшуються обчислювальні операції в режимі реального часу), ніж повна зворотна динаміка, яка має що змінюються в часі нелінійні параметри. Ця лінеаризация може викликати деяку помилку моделювання і погіршити характеристики стеження керування на основі зворотної динаміки. Помилки моделювання, викликані

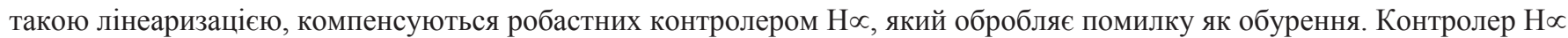
відіграє роль ослаблення не тільки збурення, викликаного невизначеністю моделювання, але також помилки неузгодженості, викликаної ПІД-регулятором зі зворотним зв'язком.

Для робастних схем керування недоліком $\epsilon$ неможливо їх застосування, якщо невизначеності або помилки у вимірах або оцінках 6 DOF-даних є великими або не можуть бути обмежені.

В роботі [5] представлено реалізація адаптивного методу керування спільно зі зворотною задачею динаміки в робочому просторі гексаподу. В адаптивному регуляторі виконується ідентифікація параметрів в режимі реального часу для налаштування параметрів регулятора, тим самим оцінки матриць в рівнянні динаміки гексаподу оновлюються, щоб різниця між справжніми значеннями цих матриць і їх оцінками сходилося до нуля.

Недоліком можна вважати те, що при реалізації цього адаптивного закону має бути відомо прискорення $\ddot{r}$, а $\hat{M}\left(r_{1}\right)$ має бути оборотна для обчислення параметрів в законі адаптації.

У загальному випадку виконання паралельним маніпулятором 6 DOF технологічних операцій, що вимагають переміщення і орієнтації робочого органу при дії обмежень на змінні стану у вигляді зовнішніх сил і зв'язків, призводить до необхідності комбінації позиційного і силового керувань [12]. Основне завдання керування при позиційному і силовому регулюванні - не окреме відстеження просторової або силовий траєкторій, а регулювання співвідношення між параметрами переміщень і силою (моментів). Це свого роду керовані зв'язки, що накладаються на зміну регульованих координат, тобто в загальному випадку необхідно говорити про керування при змішаних обмеженнях. У таких випадках гексапод повинен бути оснащений великою кількістю датчиків, крім звичайних датчиків руху, повинен мати можливість контролювати взаємодіючі сили. Оскільки в паралельних роботах можуть використовуватися різні типи вимірювальних блоків, для реалізації такої каскадної структури можуть бути побудовані різні керуючі структури на основі варіацій вимірювання положення і сили.

В роботі [5] представлено використання замкнутої системи керування гексаподом в якій зовнішній зворотний зв'язок по силі, а внутрішній по положенню чи на оборот. У першому випадку помилка стеження буде визначатися за значенням сили, а головний регулятор розробляється для задоволення характеристик стеження сили, змінні руху вимірюється і використовується у внутрішньому контурі зворотного зв'язку, тим самим контролюється динамічне співвідношення між силою і змінними руху.

У статті [13], пропонується новий алгоритм керування імпедансом (опором), заснований на змінній матриці жорсткості, для маніпуляторів паралельної з'єднання без вимірювання положення верхньої платформи. Цей метод вимагає вимірювання довжини ланок, їх швидкості і сили, створюваної навколишнім середовищем, і заснований на лінеаризації нелінійної динаміки на підставі, що область руху гексаподу навколо робочої точки мала. Одна 3 ключових ідей - змінити матрицю жорсткості імпедансу (опору) моделі, щоб компенсувати помилки параметрів динаміки моделі.

Як недолік можна помітити, що для гарної характеристики керування опором потрібно точна модель системи, а отримана сила і динаміка руху не є стійкими до невизначеності моделювання. 


\section{2. Аналіз існуючих систем керування рухом гексаподу}

Аналіз структурних схем систем керування рухом паралельних маніпуляторів і врахування положень теорії автоматичного управління дозволили визначити, що незалежно від сфери застосування все системи керування механізмами паралельної структури можуть бути класифіковані як багатовимірні системи, що стежать одно або двоконтурні $з$ корекцією по збуренню чи ні. Як доведено в джерелах $[14,15]$ традиційні системи, що стежать обмежують можливості підвищення точності виконання заданої траєкторії за рахунок зменшеної кількості ступенів вільності при виборі структури регулятора, оскільки регулятор складається з одного елемента 3 передавальної функції W.

Вивчення методів розробки систем керування рухом механізмів з паралельною кінематикою доводить, що всі вони спрямовані на оптимізацію використання набору автономних ПІД регуляторів в контурах керування за рахунок налаштування їх коефіцієнтів [7, 5]. Однак, ще у відомій монографії [16] доведено, що така оптимізація обмежує граничні межі точності керування, які можуть бути забезпечені в оптимальній системі. Досягнення високих рубежів якості стеження можливо лише в таких системах, де і структура і параметри закону керування вибрані відповідно до динаміки об'єкта управління, програмного сигналу збурень і похибок вимірювання.

Крім цього вивчення методів розробки систем керування рухом робочого органу гексаподу показало, що 3 метою спрощення моделі об'єкта керування і процедур проектування системи керування, часто пропонується поділ механізму на окремі автономні канали за кількістю штанг паралельної кінематики [17, 7], нехтуючи похибками вимірювання i динамікою датчиків, використання ідеалізованих віртуальних моделей механізму паралельної кінематики для формування сигналів корекції. При цьому замінюються реальні характеристики платформи Стюарта (гексапод) лінеаризованими, а збурюючі дії - взаємовпливом висей їх оцінками [8-11].

У той же час, з багатьох літературних джерел, наприклад $[2,5,12,17]$, відомо, що механізми паралельної кінематики відноситься до багатовимірним об'єктів керування, динаміка яких залежить від сфери його застосування. Отже, поділ об'єкта на канали повинно грунтуватися на аналізі динаміки об'єкта керування, а не на бажанні конструктора спростити розрахунки. Крім цього, облік перехресних зв'язків у багатьох випадках $[15,18,19]$ дозволяє істотно підвищити якість керування. 3 іншого боку, як доведено в $[20,21]$ забезпечити автономність каналів багатовимірного об'єкта керування засобами автоматики можливо тільки в разі, коли в перехресних зв'язках відсутні входи сигналів і об'єкт керування є стійким і мінімально фазовим.

Також поширені методи динамічного керування, при яких формування керуючих сигналів здійснюється 3 урахуванням рівнянь динаміки маніпулятора. При цьому за рахунок ускладнення керування вдається подолати негативний вплив нелінійностей і перехресних зв'язків, підвищити якість процесу керування, забезпечити його стійкість незалежно від конкретної траєкторії [6, 7, 12]. Фактор, який обмежує якість управління механізмом, пов'язаний зі складністю аналітичного визначення лінеаризованної моделі динаміки. Така складність пов'язана 3 необхідністю врахування керуючих моментів приводів, сил тертя, зовнішніх сил і моментів, відцентрових і коріолісових сил, значення яких відомі не повністю:

• пружних деформацій ланок, люфтів в механічних передачах, похибок виготовлення і збірки, вузлів;

- змінних наведених моментів інерції та мас механізму і навантаження.

Ще один спільний недолік існуючих систем керування, який обмежує можливості підвищення точності стеження, $є$ нехтування динамікою інтелектуальних датчиків інформації і шумами, які супроводжують вимірювання.

\section{3. Шляхи подолання обмежень існуючих систем керування рухом гексаподу} дій:

Для подолання наслідків недоліків систем керування механізмами паралельної кінематики пропонується кілька

- змінити структурні схеми слідкуючих систем на схеми, у відповідності до монографії [14, 15] які мають потенційно високою точністю відтворення програми за рахунок збільшення ступенів вільності у виборі регулятора (рис. 2,3);

• з огляду на призначення механізму, обгрунтувати відмову від подання такого механізму набором автономних одновимірних елементів і визначити моделі динаміки вектора програмних сигналів $\mathrm{r}_{0}$;

• на основі аналізу літературних джерел і в результаті вивчення характеристик шумів вимірювання і динаміки датчиків скласти відповідні математичні моделі;

• визначити лінеаризовану модель динаміки механізму паралельної структури і визначити ії зв'язок з координатами платформи;

• на основі диференціального перетворення Пухова Г.Є. спростити алгоритми розв'язання прямої та зворотної задач кінематики;

• відмовитися від оптимізації тільки параметрів набору автономних ПІД регуляторів;

• визначити структуру і параметри матриць передавальних функцій регуляторів, які враховують динаміку векторів програмних сигналів, збурень і шумів, забезпечують стійкість системи керування, доставляють екстремум обраним критерієм якості і мають робасні властивості; 
- досліджувати, як змінюється стійкість системи і якість спостереження в результаті дії невизначеностей, щодо характеристик елементів системи керування і сигналів в контурі керування.

\section{Висновки}

На основі представлених методів керування рухом паралельного маніпулятора 6 DOF, а також вивчення принципів керування багатозв'язними об'єктами можна зробити висновок, що практично будь-який з методів передбачає лінеаризацію і / або децентралізоване управління, засноване на декомпозиції системи. Складність динаміки гексаподу не дозволяє здійснити децентралізоване управління без урахування сил взаємовпливу між ступенями рухливості в кінематичних ланцюгах і дії навантаження. Для деяких режимів роботи гексаподу спрощена модель динаміки не буде відображати реальних фізичних процесів, що відбуваються в гексаподі, що негативно позначається на керованості механізму в цілому. Загального підходу до побудови системи керування немає, тому необхідно привести рівняння динаміки гексаподу до лінеаризованого вигляду вводячи додаткові бажані зв'язки або вводячи додаткові зворотні зв'язки до об'єкта керування або комбінація з них.

Проведений аналіз дозволив запропонувати структурні схеми керування рухом гексаподу побудовані за принципом одно, двоконтурних слідкуючих систем. Виходячи з недоліків слідкуючих систем, запропоновано будувати систему керування гексаподом на основі схем що мають потенційно більшу точність відтворення програмного керування за рахунок збільшення ступеня вільності у виборі регулятора. Для цього визначено ряд дій.

\section{Список використаних джерел}

[1] Lung-Wen Tsai. Systematic Enumeration of parallel Manipulators // Technical research report (T.R.98-33).-Institute for system recearch.-P.l-9. URL: https://drum.lib.umd.edu/handle/1903/5951 (дата звернення: 02.05.2018).

[2] Merlet, J.-P., Parallel Robots, Springer, 2nd edition, 2006. 394 p.

[3] Nonlinear Robust Control Design for a 6 DOF Parallel Robot. Dong Hwan Kim, Ji-Yoon Kang and Kyo-II Lee / Received November 11, 1998.

[4] Davliakos, I., \& Papadopoulos, E. Model-based control of a 6-dof electrohydraulic Stewart-Gough platform. Mechanism and Machine Theory, vol. 43, no. 11, pp. 1385-1400, 2008.

[5] Parallel Robots. Mechanics and Control. Hamid D. Taghirad. CRC Press; 1 edition, by Taylor \& Francis Group, 2013, 533 pages.

[6] Крутько П.Д. Обратные задачи динамики управляемых систем: Линейные модели. - М.: Наука. Гл. физ.-мат. лит., 1987. -304c.

[7] Быканова А. Ю. Системы дистанционного управления многостепенными объектами параллельной кинематической структуры. 05.13.06 - Автоматизация и управление технологическими процессами и производствами (в машиностроении). Диссертация на соискание ученой степени кандидата технических наук. Владивосток - 2004.

[8] Robust nonlinear task space control for 6 DOF parallel manipulator Hag Seong Kima,Young Man Chob, Kyo-II Lee / Automatica 41 (2005) 1591 - 1600.

[9] Space Approach of Robust Nonlinear Control for a 6 DOF Parallel Manipulator. Hag Seong Kim. Agency for Defense Development, Korea Parallel Manipulators, New Developments, Book edited by: Jee-Hwan Ryu, ISBN 978-3-90261320-2, pp. 498, April 2008.

[10] Active disturbance rejection control of a parallel manipulator withself learning algorithm for a pulsating trajectory tracking task. A. Noshadi, M. Mailah Scientia Iranica B (2012) 19 (1), 132-141.

[11] Position control of a Stewart platform using inverse dynamics control with approximate dynamics. Se-Han Lee, JaeBok Song, Woo-Chun Choi, Daehie Hong Department of Mechanical Engineering, Korea University, 5, Anam-dong, Sungbuk-gu, Seoul 136-701, Korea.

[12] Позиционно-силовое управление робототехническими и мехатронными устройствами: монография / И. Н. Егоров ; Владим. гос. ун-т. - Владимир: Изд-во Владим. гос. ун-та, 2010. - 192 с.

[13] Impedance Control with Varying Stiffness for Parallel-Link Manipulators. Jong H. Park and Hyun C. Cho / Proceedings of the American Control Conference Philadelphia, Pennsylvania June 1998, 478-482p.

[14] Оптимизация линейных инвариантных во времени систем управления: (монография) /Ф.А. Алиев, В.Б. Ларин, К.И. Науменко, В.Н. Сунцев; Ин-т математики АН УССР.- К.: Наук. думка, 1978.- 327с.

[15] Азарсков В.Н. Методология конструирования оптимальных систем стохастической стабилизации: Монография / В.Н. Азарсков, Л.Н. Блохин, Л.С. Житецкий / Под ред. Блохина Л.Н. - К.: Книжное издательство НАУ, 2006. - 440c.

[16] Фельдбаум А.А. Основы теории оптимальных автоматических систем/ Фельдбаум А.А. - М.: Наука, 1966. $623 \mathrm{c}$.

[17] Подураев Ю.В. Основы мехатроники: Учебное пособие. - М.: МГТУ «СТАНКИН», 2000 - 80с.

[18] Анализ и управление большими космическими конструкциями: (Монография) / М.З. Згуровский, П.И. Бидюк; НТУУ «КПИ».- К.: Наукова думка, 1997.- 451с. 
[19] Осадчий С.И. Комбинированный метод синтеза оптимальных систем стабилизации многомерных подвижных объектов при стационарных случайных воздействиях / С.И. Осадчий, В.А. Зозуля. // Международный научнотехнический журнал «Проблемы управления и информатики». - 2013. - №3. - С. 40-49.

[20] Методы классической и современной теории автоматического управления: Учебник в 5-и тт.; 2-е изд., перераб. и доп. Т.3: Синтез регуляторов систем автоматического управления / Под ред. К.А. Пупкова и Н.Д. Егупова. - М.: Издательство МГТУ им. Баумана, 2004.- 616с.

[21] Системний аналіз складних систем управління: Навч. посіб. / А.П. Ладанюк, Я.В. Смітюх, Л.О. Власенко та ін. - К.: НУХT, 2013. - 274c.

\section{References}

[1] Lung-Wen Tsai. Systematic Enumeration of parallel Manipulators // Technical research report (T.R.98-33).-Institute for system recearch.-P.l-9 . URL: https://drum.lib.umd.edu/handle/1903/5951 (data zvernennya: 02.05.2018).

[2] Merlet, J.-P., Parallel Robots, Springer, 2nd edition. P. 394, 2006.

[3] Nonlinear Robust Control Design for a 6 DOF Parallel Robot. Dong Hwan Kim, Ji-Yoon Kang and Kyo-II Lee / Received November 11, 1998.

[4] Davliakos, I., and Papadopoulos, E. Model-based control of a 6-dof electrohydraulic Stewart-Gough platform. Mechanism and Machine Theory, vol. 43, no. 11, pp. 1385-1400, 2008.

[5] Parallel Robots. Mechanics and Control. Hamid D. Taghirad. CRC Press; 1 edition, by Taylor \& Francis Group. P. 533, 2013.

[6] Krutko P.D. Obratnyye zadachi dinamiki upravlyayemykh sistem: Lineynyye modeli. M.: Nauka. Gl. fiz.-mat. lit. P. 304, 1987.

[7] Bykanova A. Y. Sistemy distantsionnogo upravleniya mnogostepennymi ob"yektami parallel'noy kinematicheskoy struktury. 05.13 .06 - Avtomatizatsiya i upravleniye tekhnologicheskimi protsessami i proizvodstvami (v mashinostroyenii). Dissertatsiya na soiskaniye uchenoy stepeni kandidata tekhnicheskikh nauk. Vladivostok. 2004.

[8] Robust nonlinear task space control for 6 DOF parallel manipulator Hag Seong Kima,Young Man Chob, Kyo-II Lee / Automatica 41. Pp. 1591 - 1600, 2005.

[9] Task Space Approach of Robust Nonlinear Control for a 6 DOF Parallel Manipulator. Hag Seong Kim. Agency for Defense Development, Korea Parallel Manipulators, New Developments, Book edited by: Jee-Hwan Ryu, ISBN 978-3902613-20-2, pp. 498, April 2008.

[10] Active disturbance rejection control of a parallel manipulator withself learning algorithm for a pulsating trajectory tracking task. A. Noshadi, M. Mailah Scientia Iranica B (2012) 19 (1), 132-141.

[11] Position control of a Stewart platform using inverse dynamics control with approximate dynamics. Se-Han Lee, JaeBok Song, Woo-Chun Choi, Daehie Hong Department of Mechanical Engineering, Korea University, 5, Anam-dong, Sungbuk-gu, Seoul 136-701, Korea.

[12] Pozitsionno-silovoye upravleniye robototekhnicheskimi i mekhatronnymi ustroystvami: monografiya / I. N. Egorov ; Vladim. gos. un-t. - Vladimir: Izd-vo Vladim. gos. un-ta. P. 192, 2010.

[13] Impedance Control with Varying Stiffness for Parallel-Link Manipulators. Jong H. Park and Hyun C. Cho / Proceedings of the American Control Conference Philadelphia, Pennsylvania June. Pp. 478-482, 1998.

[14] Optimizatsiya lineynykh invariantnykh vo vremeni sistem upravleniya: (monografiya) /F.A. Aliyev, V.B. Larin, K.I. Naumenko, V.N. Suntsev; In-t matematiki AN USSR.- K.: Nauk. dumka. Pp. 327, 1978.

[15] Azarskov V.N., Blokhin L.N., Zhitetskiy L.S. Metodologiya konstruirovaniya optimal'nykh sistem stokhasticheskoy stabilizatsii: Monografiya. K.: Knizhnoye izdatel'stvo NAU. P. 437, 2006.

[16] Feldbaum A.A. Osnovyi teorii optimalnyih avtomaticheskih sistem/ Feldbaum A.A. - M.: Nauka. P. $623,1966$.

[17] Poduraev Yu.V. Osnovy mekhatroniki: Uchebnoye posobiye. - M.: MGTU «STANKIN». P. 80, 2000.

[18] Analiz i upravleniye bol'shimi kosmicheskimi konstruktsiyami: (Monografiya) / M.Z. Zgurovsky, P.I. Bidyuk; NTUU «KPI».- K.: Naukova dumka. P. 451, 1997.

[19] Osadchiy S.I. Kombinirovannyiy metod sinteza optimalnyih sistem stabilizatsii mnogomernyih podvizhnyih ob'ektov pri statsionarnyih sluchaynyih vozdeystviyah / S.I. Osadchiy, V.A. Zozulya. // Mezhdunarodnyiy nauchnotehnicheskiy zhurnal «Problemyi upravleniya i informatiki». \#3. Pp. 40-49, 2013.

[20] Metody klassicheskoy i sovremennoy teorii avtomaticheskogo upravleniya: Uchebnik v 5-i tt.; 2-ye izd., pererab. i dop. T.3: Sintez regulyatorov sistem avtomaticheskogo upravleniya / Pod red. K.A. Pupkova and N.D. Egupova. - M.: Izdatel'stvo MGTU im. Baumana. P. 616, 2004.

[21] Systemnyy analiz skladnykh system upravlinnya: Navch. posib. / A.P. Ladajuk, Ya.V. Smythyuk, L.O. Vlasenko ta in. - K.: NUKHT. P. 274, 2013. 